Article

\title{
Developing and Validating a Theory-Based Model of Crowdfunding Investment Intention-Perspectives from Social Exchange Theory and Customer Value Perspective
}

\author{
Xiaocong Yang ${ }^{1,+}$, Kai Zhao ${ }^{2, *,+} \mathbb{D}$, Xiaobo Tao $^{3}$ and Eric Shiu ${ }^{4}$ \\ 1 Department of Public Administration, Guangzhou University, Guangzhou 510006, China; \\ xc.yang@gzhu.edu.cn \\ 2 School of Economics and Finance, Xi' an Jiaotong University, Xi'an 710061, China \\ 3 School of Economics and Management, North China University of Technology, Beijing 100144, China; \\ bob.tao@ncut.edu.cn \\ 4 Department of Marketing, Birmingham Business School, University of Birmingham, Birmingham B15 2TT, \\ UK; e.c.shiu@bham.ac.uk \\ * Correspondence: kaizhao@mail.xjtu.edu.cn \\ + These authors contributed equally to this article.
}

Received: 8 April 2019; Accepted: 28 April 2019; Published: 1 May 2019

\begin{abstract}
In order to improve public financing sustainability in China, the Chinese government has announced several administrative policies on crowdfunding, concerning platform construction and operation, in recent years. However, the existing policy scope rarely mentions the importance of social psychology, which also plays a decisive role in determining the participation and success rates of crowdfunding. Therefore, this study uses the knowledge from social exchange theory (SET) and customer value perspective (CVP) to develop and validate a conceptual model of the key determinants of the public's intention in investing in crowdfunded projects in China. Based on the primary survey data, the SEM (structural equation modeling) estimations suggest that: (1) communication, shared values, investors' perceived benefits, and perceived risk have significant effects on crowdfunding investors' trust in fundraisers of a particular crowdfunding project, which in turn act on their commitment and intentions to invest in the project; (2) trust strengthens funding intentions through fulfilling commitments, whereas its direct effect on funding intentions is insignificant; (3) commitment has a direct and significant positive effect on the enhancement of funding intentions. These findings propose a new perspective of improving public policies to support small and micro enterprises (SMEs) and individual innovative projects in China.
\end{abstract}

Keywords: crowdfunding; investment intention; social commerce; structural equation modeling

\section{Introduction}

Crowdfunding provides an alternative source of finance on the Internet for small and micro enterprises (SMEs) and private businesses to fund their projects. These SMEs and individual businesses are often denied loans by banks, and therefore crowdfunding may become their only hope to obtain the finance needed for their projects [1,2]. What they need to do is to log onto a crowding platform such as Kickstarter or Indiegogo, post the plan of their projects-including the amount of capital required-and then use videos or texts to explain their projects [3].

Crowdfunding is mostly needed in the start-up phase of a project, but it may also be needed in the expansions phase [4]. It facilitates the financing process by providing a platform, which stimulates 
individuals' passion for sharing their business ideas with others and can be classified as rewards, donation, debt, or equity-based financing [5]. Crowdfunding has been on the rise for the past few years [6,7]. However, its development has been hindered by seemingly reduced investment intentions. For example, approximately $43 \%$ of all funded projects raised adequate finance on Kickstarter in 2014, but this reduced to $36 \%$ in the following year [8]. Similarly, the development of crowdfunding also has been through a difficult initial stage in China. According to The Development Report of Crowdfunding 2018 [9], the total number of crowdfunding platforms and the total amount of funds raised are 76 and 14.4 billion CNY (2.15 billion USD), respectively, by the end of 2017 , which reduced by $36 \%$ and $10 \%$, respectively, compared to the same period of 2016. Most of the crowdfunding platforms in China must not only face the policy changing, but also face challenges such as harsh market competition or low capital acquisition rate. Scholars have proffered several explanations for this development dilemma, including the shortage of product category, the ineffectiveness of supervision, or an imperfect operation model [10-13]. Moreover, some researchers have also noted that limited participation was crucial in determining the slowdown [14]. Previous research engaged in this aspect has focused on the design or development of methods for identifying factors that visually affect the intentions of crowdfunding participation, such as geography [15], social network relationship [16], or product features [17]. However, this strand of literature, to a certain degree, ignored the possible intangible exchanges (e.g., feelings and belongings) between investors and recipients during the crowdfunding process, which also plays a decisive role in determining crowdfunding intentions. The lack of research in this domain means it remains unclear how intangible benefits could forge investors' perceptions of a crowdfunding project in complicated communication scenarios. In addressing these shortcomings, the present study seeks appropriate answers to the following questions: (a) What are the effects of different intangible factors (perceived benefits, communication, shared value, perceived risks, trust, and commitment) on investors' crowdfunding intentions? (b) How the different intangible factors could help fundraisers and investors come together in the most efficient manner through the process of social value exchange. This study provides two main contributions to the current literature regarding crowdfunding in China. On one hand, we intend to integrate social exchange theory (SET) with the customer value perspective (CVP) theory in the crowdfunding context. An increasing amount of research focuses on crowdfunding [18-21] and has contributed theoretically to improving crowdfunding investment intentions, although without much mention of how crowdfunding is built on crowdsourcing [22], which is itself a new form of social commerce [23]. Some scholars have perceived crowdfunding as an emerging and critical form of social commerce [24]. From the perspective of social commerce [25], the relationship between crowdfunding investors and initiators involves not only mutual benefits, but also emotional interaction and social engagement. Accordingly, socialization plays a major role in the formation of investment intentions. Along this line of thought, this study adopts the social exchange theory (SET) and the customer value perspective (CVP) together to develop hypothetical factors that could affect crowdfunding investment intentions in the context of social commerce. On another hand, this paper provides meaningful materials and references for financial regulators in China to understand how social funds could be effectively made together in the area of an urgent need for SMEs. At this point, this paper is one of the few studies that directly focus on investors' intentions for crowdfunding in mainland China and provide a novel empirical demonstration of how the interaction of multiple factors can serve as a noteworthy determinant of crowdfunding success. Compared to the current research in the context of Asia [3,26], the findings of this paper expect to bring more insights into crowdfunding investor's behaviors.

In conducting this research, we explicitly modeled the level of crowdfunding intention as a function of intangible and tangible factors, such as perceived benefits, communication, shared value, perceived risks, trust, commitment, and the market prospects of the crowdfunding project. We conceptualize this analytical framework for three reasons. First, social exchange theory posits that trust and commitment are essential to exchange relationships. Both trust and commitment have been proven to have a strong effect on reinvestment or purchase intentions [27]. Therefore, this study utilizes 
trust and commitment, which have been proposed by Morgan and Hunt [28] as mediating variables in crowdfunding investment intentions. Second, many studies based on the social exchange theory have suggested that communication and shared values are central to exchange relationships and strongly affect partnerships [29-31]. Thus, this study uses communication, shared values, and perceived benefits as antecedents of trust and commitment to develop a conceptual model. Finally, from the perspective of customer value, risks can affect consumer behavior and intentions, and the perceived benefits may reduce the utilization disorders of consumers, thereby mitigating their perceived risks. Accordingly, the relationship between perceived risks and investment intentions is examined as well.

The remainder of this paper is structured as follows. Section 2 reviews relevant theories and presents the hypotheses for the present study. Section 3 introduces the research design, which comprises sampling and data collection methods as well as the research model and variable definitions. Section 4 describes the analysis results. Section 5 provides the conclusion of this study and recommends strategies for improving crowdfunding investment intentions, discusses the limitations of this study, and proposes directions for future research.

\section{Literature Review and Hypothesis Development}

It is important to state that the conceptual model employed in this study does not argue for a mechanistic relationship between one tangible factor and crowdfunding intention. Instead, we argue that fundraising could be made more efficient and productive by acting through three key mechanisms. First, communication, shared values, perceived risks, and perceived benefits, as the important intangible factors, could have substantial effects on forming trust, which is a crucial determinant of commitment and crowdfunding intention. Therefore, we propose the following hypotheses.

The level of communication between an investor and a fundraiser can positively affect the investor's trust in the fundraiser. Communication is a process through which one person conveys his or her messages, thoughts, and feelings to another person, in anticipation that the person might respond in an identical manner [32]. Trust is established when the trustor decides that the other party is trustworthy; this belief generates trusting intention [33]. Previous studies have shown that nonprofit organizations have difficulty influencing investor values, but they can attract donations and investment from their investors by consistently communicating with them to enhance mutual trust [34]. Thus, communication with investors is vital to nonprofit organizations [35]. Zehir et al. [36] have found that communication positively affects consumer trust because it helps to establish further relationships between brands and customers. Chao et al. [37] sampled medical equipment suppliers and observed a positive correlation between communication and trust. Leonidou et al. [38] have examined the outcomes of exporter-importer relationship quality, arguing that communication positively affects trust because: (1) cultural and linguistic differences exist between both parties; (2) accessing timely, accurate, and updated information about the foreign partner's country is difficult; and (3) the geographical separation between both parties can cause time delays and increase costs of information acquisition. Against a backdrop of the above previous studies, this study argues that a crowdfunding investor's communication with a fundraiser positively affects their trust in the fundraiser. In other words, if a fundraiser frequently communicates with an investor, provides helpful information, or notifies the investor of urgencies, then the investor's trust in the fundraiser could be enhanced. Effective communication is a precondition for building trust between people in E-commerce [33]. Hypothesis 1 is therefore proposed as follows.

H1. In crowdfunding activities, the frequency of communication between an investor and fundraiser could positively affect the investor's trust-level in the fundraiser.

The presence of shared values between an investor and a fundraiser positively affects the investor's trust in the fundraiser. Shared values refer to the sum of beliefs, values, goals, and a series of agreed-upon actions that prevail in a group and consistently enable the group to complete tasks or corporate objectives [39]. In addition, shared values reflect the level at which both individuals share 
common perceptions regarding the subjects of behavior, strategies, and the importance and suitability of different objectives, and they may involve the level of common perceptions regarding the quality, practicality, and ethical grounding of the values [28]. Accordingly, during interpersonal interactions, partners may learn about each other's actions through experience and observation, to determine whether they have shared values and whether they should base their future actions (e.g., deciding whether to trust the other party or maintain the relationship) on their interaction outcomes and each other's opinions. Chang and Hsiao [39] found that social network service members with shared values prefer to use interactive system platforms to enhance their communication and interaction. Thus, shared values directly affect their intention to use social recommender systems and have the strongest positive influence on trust, which mediates the significant effect of shared values and reputation on the intention to use social recommender systems. On the basis of these studies, the present study argues that shared values between a crowdfunding investor and a fundraiser positively affect the investor's trust in the fundraiser $[35,38]$. In other words, if both the investor and the fundraiser share common values or have similar opinions and thoughts, then the investor's trust in the fundraiser may be improved, and both the investor and the fundraiser may endeavor to maintain their partnership, which is built on mutual trust. Hypothesis 2 is therefore proposed as follows.

H2. In crowdfunding activities, the degree of shared values between an investor and a fundraiser could positively affect the investor's trust-level in the fundraiser.

Investor's perceived benefits of a crowdfunding project can positively affect their trust in the project. Perceived benefits refer to a person's perceived favorable outcomes from taking an action, or their subjective assessment of personal gains as a result of this action. Kuo and Feng [40] divided the perceived benefits of online brand communities into learning, social, self-esteem, and hedonic benefits, and have examined how they affected commitment to online automobile brand communities. They found that all but self-esteem benefits were shown to significantly influence community commitment because, within the online communities, few members had sufficient automobile expertise to enable them to provide problem-solving support. In addition, those members who possessed expertise derived self-esteem benefits from interacting with others during this process. Dhar [41] investigated the relationship between employee training and service quality in hotels in India and found that hotel employees' commitment mediated the positive effects of their perceived training opportunities, perceived benefits from training, and perceived organizational support for training on their service quality, and that perceived benefits from training had the highest influence on trust. On the basis of these previous studies, this study argues that a crowdfunding investor's perceived benefits of a crowdfunding project positively affect their trust in the projects. In other words, if an investor believes that they can obtain product-related knowledge, expand their personal networks, enhance their personal reputation, or derive joy by engaging in certain crowdfunding projects, then the investor's trust in the projects may be improved. Hypothesis 3 is therefore proposed as follows.

H3. An investor's perceived benefits of a crowdfunding project could positively affect their trust-level in the project.

Perceived risks are a customer's perceived unfavorable outcomes from obtaining a product, or their subjective assessment of losses associated with obtaining the product. As a result, it is likely to negatively affect their trust in a project [42]. The majority of emerging research regarding the role of perceived risk within the decision-making process has been extended to multiple perspectives. For instance, Hong and Cha [43] have investigated factors affecting online purchase intentions. They have divided perceived risks into performance, psychological, social, financial, online, and payment risks. Their research work has found that trust directly affects purchase intentions and that performance and financial risks affect purchase intentions through trust. Cho et al. [44] have examined the effects of wine attributes, perceived risks, and wine website quality on repurchase intentions by administering questionnaires to online wine club members in the United States. They found that perceived risks have 
a negative association with online wine repurchase intentions; wine origin and consumer perception about wines affect repurchase intentions through perceived risks, and the quality of information and service of online wine websites moderates the effects of wine origin attributes on perceived risks associated with online wine repurchasing. Following these previous research results, this study argues that an investor's perceived risks of a crowdfunding project can negatively affect their trust in the project. Hypothesis 4 is therefore proposed as follows.

H4. An investor's perceived risks of a crowdfunding project could negatively affect their trust-level in the project.

Second, trust and commitment signal underlying mechanisms that increase the crowdfunding intentions. Therefore, we propose the following hypotheses.

H5. In crowdfunding activities, an investor's trust-level in a fundraiser positively affects their degree of commitment to the fundraiser.

H6. In crowdfunding activities, an investor's trust-level in a fundraiser positively affects their level of investment intention.

In the classical relational marketing model, Morgan and Hunt [28] proposed that trust and commitment were key mediating variables. If they were just identified as two independent antecedents of important relationship outcomes, failing to include their interactional effects would result in flawed conclusions regarding not only the direct impact of commitment and trust on the outcomes, but also the indirect effects that commitment and trust have with other explanatory variables. Based on this theory, the follow-up studies from different perspectives showed that increasing the level of trust can facilitate the fulfillment of commitment $[45,46]$. With this line of thought, this study suggests that a crowdfunding investor's trust-level in a fundraiser can positively affect their commitment to a fundraiser. In other words, if an investor believes that a fundraiser possesses problem-solving skills, strong ethics, and willingness that helps other investors, then this investor will help the fundraiser and cement their relationship, provided that the fundraising project satisfies the investor's needs. Hong and Cha [43] have explored online purchase intentions and suggested that the level of trust of a consumer in a shop significantly affects their purchase intentions. See-To and Ho [47] have analyzed the effects of electronic word-of-mouth on purchase intentions in social networking sites, developed a theoretical model that comprised the level of trust, purchase intentions, and electronic word-of-mouth in social networking sites as constructs, and have found that the level of trust moderates the direct effect of electronic word-of-mouth on purchase intentions of consumers. Ponte et al. [48] investigated the effects of trust-level and perceived value on the intention to purchase travel products and identify the antecedents of trust. They showed that consumers' perceived privacy has no effect on their trust in travel websites. The respondents in that study reported no concern about privacy invasion (namely, whether travel websites collect excessive personal information from them), probably because third-party certification is widely applied in E-commerce transactions. They also found that only perceived security and information quality contribute to an individual's trust-level (in particular, the respondents attached importance to information quality), trust-level and perceived value positively affect online purchase intentions, trust-level directly and positively influences purchase intentions, and perceived value mediates the effects of trust-level on purchase intentions. These studies indicate that trust-level is a crucial factor in promoting behavioral intentions. Accordingly, the present study suggests that a crowdfunding investor's trust-level in a fundraiser can positively affect their level of investment intentions.

Finally, the third mechanism for increasing crowdfunding participation is that a crowdfunding investor's commitment to a fundraiser can positively affect their investment intention. Hypothesis 7 is therefore proposed as follows.

H7. In crowdfunding activities, an investor's degree of commitment to a fundraiser positively affects their level of investment intentions. 
Commitment is a constant desire to maintain a valuable relationship, and it also refers to an emotional connection [49]. Shin et al. [50] investigated South Korean consumers' purchase intentions in online shopping and found that their trust-level and degree of commitment have an impact on their online repurchase intentions, and that both trust-level and customer satisfaction affect their online repurchase intentions through the degree of commitment. Zopiatis et al. [51] focused on factors affecting the turnover intentions of hotel employees and have found that job satisfaction has a nonsignificant effect on turnover intentions, extrinsic job satisfaction has a negative relationship with turnover intentions, normative organizational commitment has a nonsignificant effect on turnover intentions, and affective and normative organizational commitment contributes to turn over intentions through extrinsic job satisfaction. These studies indicate that commitment is a crucial factor in promoting behavioral intentions. Therefore, the present study argues that a crowdfunding investor's commitment to a fundraiser can positively influence their investment intentions. In other words, if the investor provides resources to help the fundraiser whenever necessary, or if the investor expects to further maintain their relationship with the fundraiser, then the investor is more likely to invest in fundraising projects.

A schematic picture of the model for the system of fundraising development is outlined in Figure 1 . The arrows identify the hypothesized structure of relationships between the key variables. In general, the model considers the process of increasing crowdfunding participation to be a system of relationships. It allows us to test the independent effects of SET and CVP theory related variables on crowdfunding intention, such as trust and commitment. It also enables us to parse the effects of latent factors such as perceived benefits, perceived risks, or communication on the level of trust, which in turn acts on crowdfunding intention.

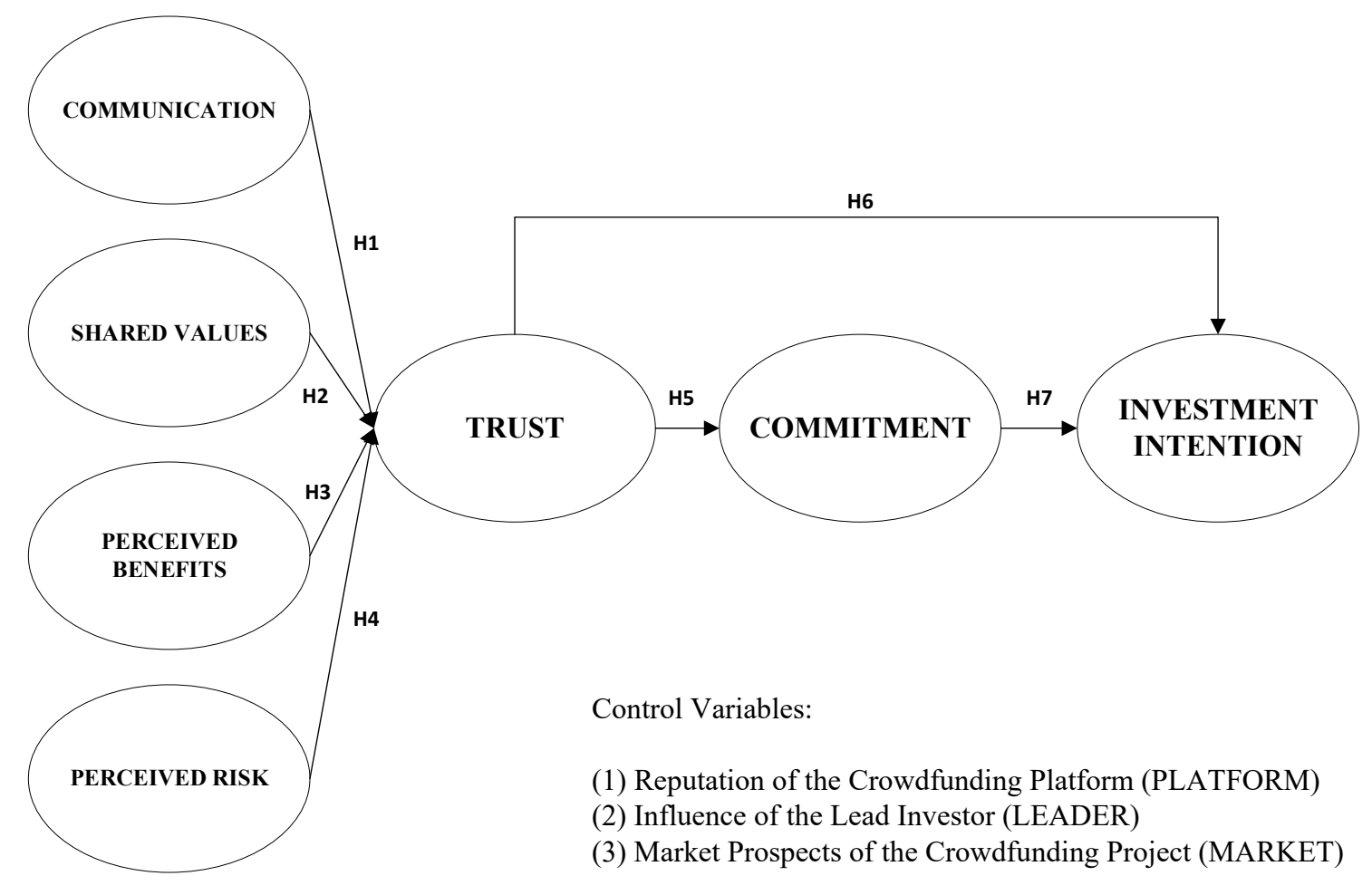

Figure 1. Analytical Framework.

\section{Methodology}

\subsection{Theoretical Model}

Following Colgren [24], the reputation of the crowdfunding platform, impact of the leading investor, and the market prospects of the crowdfunding project were used as control variables for 
controlling for the macro effects of the crowdfunding market, which are also related to crowdfunding intentions. Based on the seven hypotheses outlined in Section 2, the structural equation model (SEM) and AMOS 18.0 were utilized to investigate the relationships between the factors of communication, shared values, perceived benefits, perceived risk, trust-level, commitment, and investment intention. Based on the three key mechanisms depicted in the model (Figure 1, below), we estimated three core equations (control variables omitted):

$$
\begin{gathered}
\text { Trust }=\beta_{11} \text { Communication }+\beta_{12} \text { Shared Values }+\beta_{13} \text { Perceived Benefits }+\beta_{14} \text { Perceived Risk }+\varepsilon_{1} \\
\text { Commitment }=\beta_{21} \text { Trust }+\varepsilon_{2} \\
\text { Investment Intention }=\beta_{31} \text { Trust }+\beta_{32} \text { Commitment }+\varepsilon_{3}
\end{gathered}
$$

\subsection{Sample Collection}

The sample for our investigation derived from respondents answering our pre-designed questionnaire, which focused on the investment intention of crowdfunding investors to the fundraisers. The questionnaire was administered through Sojump.com (a professional online survey website established by Shanghai Information Technology Co. cycle in December 2005. It is the first company dedicated to providing online, self-designed questionnaires and related services in China, and it focuses on the development and operation of a questionnaire star site. For more information, please visit: http://www.sojump.com/ or https://www.crunchbase.com/organization/sojump\#/entity) and WeChat (a mobile text and voice messaging communication service and software developed by Tencent in China), and was revised following a pilot test and subsequently published on the Internet with a declaration that keeps respondents' personal information completely confidential. A total of 818 responses were received. Data cleansing was conducted in three steps: (1) exclude responses containing apparent mistakes ( $n=13,1.59 \%$ ); (2) exclude responses containing $70 \%$ of items with the same numerical value ( $\mathrm{n}=25,3.06 \%)$; and (3) exclude responses indicating that the respondent had not participated in crowdfunding $(\mathrm{n}=15,1.83 \%)$. Finally, a total of 765 valid responses were obtained, posting a valid response rate of $93.52 \%$. Among the valid responses, 505 were submitted through WeChat (66.01\%) and 260 through Sojump.com (33.99\%). Respondents came from 30 domestic regions of China (including Hong Kong), except for the one respondent from Germany. Only 151 respondents provided the full details of the crowdfunding projects and most of these projects pertained to digital technology, literacy, music, and art.

\subsection{Variable Measures and Scale Development}

The questionnaire design followed the studies of Featherman and Pavlou [52], Hong and Cha [43], and Kuo and Feng [40]. All the respondents were questioned about some specific aspects of the concepts which can qualify relevant social exchange characteristics, customer value characteristics, and investment intention. The main variable measures and scales that are related to the generation of independent and dependent variables used in this study are shown in Table 1 (columns 1 and 2) 
Table 1. Descriptive statistics for variables used, and variables (scales) factor loading (standardized) for constructing latent variables, with standard errors, t-value, and CR-value ( $\mathrm{N}=497)$.

\begin{tabular}{|c|c|c|c|c|c|c|c|c|c|}
\hline Latent Variables & Measurement Item & Mean & S.D. & Skewness & Kurtosis & $\begin{array}{c}\text { Standardized } \\
\text { Factor Loading }\end{array}$ & S.E. & t-Value & CR-Value \\
\hline \multirow{5}{*}{ Communication } & 1. Immediate communication with the fundraiser & 5.30 & 1.42 & -0.75 & 3.00 & 0.88 & 0.03 & $32.17 * * *$ & \\
\hline & 2. Accurate communication with the fundraiser & 5.37 & 1.41 & -0.82 & 3.25 & 0.9 & 0.03 & $33.50^{* * *}$ & \\
\hline & 3. Sufficient communication with the fundraiser & 5.24 & 1.49 & -0.71 & 2.94 & 0.91 & 0.03 & $33.98^{* * *}$ & 0.948 \\
\hline & 4. Complete communication with the fundraiser & 5.23 & 1.45 & -0.78 & 3.10 & 0.89 & 0.03 & $33.15^{* * *}$ & \\
\hline & 5. Reliable communication with the fundraiser & 5.40 & 1.43 & -0.91 & 3.46 & 0.85 & & & \\
\hline \multirow{3}{*}{ Shared Values } & 1. Shared similar viewpoints and values with the fundraiser & 5.41 & 1.30 & -0.98 & 4.16 & 0.86 & 0.05 & $23.58 * * *$ & \\
\hline & 2. Like and respect the fundraiser's values & 5.63 & 1.30 & -1.01 & 3.93 & 0.85 & 0.05 & $23.24^{* * *}$ & 0.858 \\
\hline & 3. Shared nearly the same values with the fundraiser & 5.44 & 1.31 & -0.93 & 3.93 & 0.74 & & & \\
\hline \multirow{13}{*}{ Perceived Benefits } & $\begin{array}{l}\text { 1. Increases knowledge and understanding of the products by participating in the } \\
\text { crowdfunding }\end{array}$ & 5.62 & 1.21 & -1.01 & 4.36 & 0.88 & 0.03 & $36.12^{* * *}$ & \\
\hline & $\begin{array}{l}\text { 2. Helps to solve a series of usage problems about the product by participating in the } \\
\text { crowdfunding }\end{array}$ & 5.48 & 1.24 & -0.77 & 3.63 & 0.91 & 0.03 & $38.90^{* * *}$ & 0.93 \\
\hline & $\begin{array}{l}\text { 3. Improve the understanding of the development or technology of the product in the } \\
\text { future }\end{array}$ & 5.58 & 1.24 & -1.00 & 4.25 & 0.92 & & & \\
\hline & 4. Expands social networking & 5.16 & 1.51 & -0.70 & 2.95 & - & - & - & - \\
\hline & 5. Intensifies relationship with other members & 5.29 & 1.37 & -0.81 & 3.48 & - & - & - & - \\
\hline & 6. Gets acquainted with other individuals who have common benefits & 5.39 & 1.39 & -0.82 & 3.41 & - & - & - & - \\
\hline & 7. Becomes famous and enhances social status & 4.94 & 1.55 & -0.58 & 2.77 & - & - & - & - \\
\hline & 8. Improves reputation and authority & 5.13 & 1.51 & -0.67 & 2.99 & - & - & - & - \\
\hline & 9. Feel satisfied while influencing other people on participation & 5.42 & 1.33 & -0.82 & 3.44 & - & - & - & - \\
\hline & 10. Feel satisfied while influencing the design and development of the project & 5.54 & 1.28 & -0.88 & 3.69 & - & - & - & - \\
\hline & 11. Feel relaxed about the project & 5.56 & 1.18 & -0.79 & 3.72 & - & - & - & - \\
\hline & 12. Feel delighted about the project & 5.59 & 1.29 & -0.96 & 3.94 & - & - & - & - \\
\hline & 13. Feel excited about the project & 5.53 & 1.23 & -0.79 & 3.59 & - & - & - & - \\
\hline \multirow{4}{*}{ Perceived Risk } & 1. Worried that the quality of the crowdfunding product cannot meet the expectations & 4.01 & 1.73 & 0.04 & 2.06 & 0.79 & 0.04 & $26.50^{* * *}$ & \\
\hline & $\begin{array}{l}\text { 2. Worried there will be a financial loss, as they cannot receive the crowdfunding } \\
\text { products }\end{array}$ & 4.06 & 1.76 & -0.09 & 2.06 & 0.87 & 0.04 & $30.73^{* * *}$ & \\
\hline & 3. Worried it will take a long time to receive the crowdfunding products & 4.38 & 1.75 & -0.36 & 2.19 & 0.84 & 0.04 & $29.29^{* * * *}$ & 0.943 \\
\hline & $\begin{array}{l}\text { 4. Worried self-esteem will be wounded as they cannot achieve the goal of the } \\
\text { crowdfunding product }\end{array}$ & 3.98 & 1.75 & -0.07 & 2.10 & 0.86 & 0.04 & $30.44^{* * *}$ & \\
\hline
\end{tabular}


Table 1. Cont

\begin{tabular}{|c|c|c|c|c|c|c|c|c|c|}
\hline Latent Variables & Measurement Item & Mean & S.D. & Skewness & Kurtosis & $\begin{array}{c}\text { Standardized } \\
\text { Factor Loading }\end{array}$ & S.E. & t-Value & CR-Value \\
\hline & $\begin{array}{l}\text { 5. Worried about family members or friends disagreeing with the participation of the } \\
\text { crowdfunding project }\end{array}$ & 3.97 & 1.80 & -0.02 & 2.03 & 0.85 & 0.04 & $29.87^{* * *}$ & \\
\hline & 6. Worried personal information could be embezzled if participating the crowdfunding & 4.30 & 1.81 & -0.17 & 2.04 & 0.81 & 0.04 & $27.56^{* * *}$ & \\
\hline & 7. Perceived there is a risk when investing in the crowdfunding project & 4.36 & 1.71 & -0.28 & 2.22 & 0.84 & & & \\
\hline \multirow{3}{*}{ Trust } & 1. Trust in the fundraiser in general & 5.41 & 1.20 & -0.67 & 3.58 & 0.8 & 0.03 & $25.52^{* * *}$ & \\
\hline & 2. The fundraiser is trustworthy & 5.47 & 1.25 & -0.77 & 3.61 & 0.89 & 0.03 & $28.73^{* * *}$ & 0.884 \\
\hline & 3. The fundraiser can keep the promise and commitment to the investor & 5.43 & 1.23 & -0.79 & 3.83 & 0.85 & & & \\
\hline \multirow{6}{*}{ Commitment } & 1. Worried there will be a loss if they give up the investment & 5.35 & 1.31 & -0.82 & 3.73 & 0.89 & 0.03 & $36.67^{* * *}$ & \\
\hline & $\begin{array}{l}\text { 2. There will be a considerable self-sacrifice if they give up investing in the fundraiser or } \\
\text { the crowdfunding project }\end{array}$ & 5.29 & 1.32 & -0.85 & 3.78 & 0.86 & 0.03 & $33.95^{* * *}$ & 0.914 \\
\hline & $\begin{array}{l}\text { 3. Personal life will be affected somehow if they give up investing in the fundraiser or } \\
\text { the crowdfunding project }\end{array}$ & 5.43 & 1.23 & -0.70 & 3.45 & 0.9 & & & \\
\hline & 4. Enjoy discussing the advantages of the crowdfunding project and fundraisers & 4.75 & 1.55 & -0.49 & 2.69 & - & - & - & - \\
\hline & 5. Feel a sense of belonging with the crowdfunding project and fundraisers & 4.57 & 1.61 & -0.40 & 2.49 & - & - & - & - \\
\hline & 6. Be attracted by crowd funding project and fundraisers & 4.51 & 1.71 & -0.41 & 2.38 & - & - & - & - \\
\hline \multirow{4}{*}{$\begin{array}{l}\text { Investment } \\
\text { Intention }\end{array}$} & 1. High probability to consider the investment of the crowdfunding project & 5.41 & 1.19 & -0.82 & 4.09 & 0.85 & 0.03 & $30.84^{* * *}$ & \\
\hline & 2. Definitely will invest in a crowdfunding project once they have made a decision & 5.47 & 1.25 & -0.83 & 3.75 & 0.84 & 0.03 & $30.01^{* * *}$ & \\
\hline & 3. High probability of investing in the crowdfunding project & 5.48 & 1.19 & -0.74 & 3.63 & 0.87 & 0.03 & $31.86^{* * *}$ & 0.916 \\
\hline & 4. Willing to invest in the crowdfunding project & 5.47 & 1.25 & -0.80 & 3.65 & 0.86 & & & \\
\hline
\end{tabular}

Notes: *** indicates $p<0.001$ 


\subsubsection{Independent Variables}

In what follows, we describe how we measured our independent latent variables.

'Communication' refers to the exchange, transmission, and sharing of information, opinions, and suggestions between investors and fundraisers, which is deemed a key indicant of the partnership's vitality [53]. Thus, effective communications between investors and fundraisers are essential [54], especially to the success of crowdfunding and investment. We measured communication based on three aspects: communication quality, the extent of information sharing between partners, and participation in planning and goal setting.

'Shared values' indicate how the investors have a consistency with the fundraiser, regarding their behavior and strategy, and the significance and appropriateness of the target project. Following MacMillan et al. [35], the measurement of shared values between investors and fundraisers encompassed three aspects. The first aspect was whether the investor has consistent values with the fundraisers in general. The second aspect indicated the degree of the investors' respect for the fundraisers' values. The last factor represented the level of shared values of both fundraisers and investors.

'Perceived benefit' indicates the perception of the positive consequences caused by a specific action [40]. In this study, the perceived benefits of investors were closely related to the specific benefits or the affective experience from the project, which play a critical role in stimulating investors' participation. Based on the definition of perceived benefits, we measured the investors' perceived values based on four categories: functional benefits (acquisition of knowledge and information about relevant products and technology), psychological benefits (sense of belonging and satisfaction of affective expectations), social benefits (having better communication and interaction with other members, expanding social networking, and getting assistance from others), and hedonic benefits (relaxation, enjoyment, and excitement from the crowdfunding project).

Bauer [55] has defined 'perceived risk' as having two elements: uncertainty of decision-making and severity of the incorrect decision. Following Bauer [55] and Bhukya and Singh [56], we divided perceived risk into six categories: financial risk, functional risk, physical risk, psychological risk, time risk, and social risk. In this study, financial risk referred to financial loss due to the quality of the project. Functional risk indicated that the function of the project did not meet investors' expectations, or it was worse than that of their competitors. The waste of time during the implementation, process, and modification of the project was the time risk, and physical risk was measured as the damage to investors' health and security from the project. Investors' affective injuries resulting from an incorrect decision were always defined as a psychological risk. In general, we defined social risk as the destructive effect on social communication due to incorrect decisions. In this research, we also followed Featherman and Pavlou [52] and brought forward a seventh risk, facet-privacy risk, which would be particularly salient for crowdfunding.

Following Pavlou [57] and Hong and Cha [43], 'trust' indicates the willingness to takes risks in the establishment of relationships, thus in this study it was defined as "whether an investor trusts in the fundraiser", "whether the fundraiser is trustworthy", and "whether the fundraiser can keep the promise and commitment". Details are shown in Table 1.

We measured 'commitment' based on two elements: affective commitment and calculative commitment. Affective commitment was defined as an emotional attachment to the relationship with a fundraiser. Affective commitment also suggests that investors have positive attitudes toward their participation in crowdfunding, such as affection, happiness, and pleasure [58]. We then defined calculative commitment as the rewards and benefits associated with participating in crowdfunding and maintaining a relationship with a fundraiser. Such commitment occurs when the investors consider that the costs of switching to another crowdfunding project are too expensive.

\subsubsection{Dependent Variable}

The dependent variable was the degree of investment intention. Following Ponte et al. [48], we measured the investment intention of crowdfunding on four scales: (a) the probability that an 
investor considers investing in a crowdfunding project (seven point Likert scale); (b) if an investor decided to invest in one crowdfunding project, they will stick to their word (seven point Likert scale); (c) the probability of an investor's investment in the specific crowdfunding project is high (seven point Likert scale); and (d) the intention to invest in this specific crowdfunding project is explicit (seven point Likert scale).

\section{Empirical Analysis}

\subsection{Reliability and Validity of the Variables}

Table 1 presents the measurement items and statistical descriptions of all scales used. Except for the three control variables (reputation of the crowdfunding platform, influence of the lead investor, and market prospects of the crowdfunding project), communication, shared values, perceived benefits, perceived risks, trust, commitment, and investment intentions were all measured on a seven point Likert's scale, with a combined total of 41 items (detailed descriptions are available upon request from authors). A data description, from Table 1, was conducted on the items to estimate the means, standard deviations, skewness, and kurtosis. In general, these results show that the sample data follows a normal distribution, rendering them suitable for further analysis. For instance, the skewness and kurtosis are closely within \pm 1 and \pm 3 , respectively.

A reliability analysis reveals that all the scales exhibit reliability of more than 0.8 . The overall reliability of the questionnaire is 0.950 , and the construct reliability of the instrument is higher than the reference level of 0.70 . These results indicate that the scales exhibited high internal consistency (Table 1). An exploratory factor analysis (EFA) reveals a Kaiser-Meyer-Olkin (KMO) value of 0.932 for all the questionnaire items [59], and all items achieve statistical significance in the Bartlett's test [60] of sphericity $(p<0.001)$. Accordingly, varimax rotation [61] was performed on the scales to extract seven common factors from all the items. The total variance explained is $76.74 \%$. All the items are subsequently reorganized. Items with factor loadings lower than 0.4 and those that overlapped multiple common factors were excluded. Varimax rotation was re-performed to simplify the EFA results. By these results, a confirmatory factor analysis (CFA) was conducted to verify the convergent validity of the scales.

The CFA model exhibits a high goodness-of-fit, as shown in Table 2 (Normed Fit Index [NFI]: 0.94; Comparative Fit Index [CFI]: 0.96; Root Mean Square Error of Approximation [RMSEA]: 0.059). The average variance extracted (AVE) for each scale was higher than 0.5, indicating that all of the scaled exhibited acceptable convergent validity. The discriminant validity of these variables was also verified. As Table 2 shows, the square root of the AVE for all the latent variables was higher than the correlation coefficients with the other variables, indicating that the variables can discriminate from the latent variables.

Table 2. Test of Convergent and Discriminant Validity: Correlation Coefficient Matrix and Square Root of AVE.

\begin{tabular}{|c|c|c|c|c|c|c|c|c|c|c|}
\hline Latent Variables & Mean & S.D. & AVE & (1) & (2) & (3) & (4) & (5) & (6) & (7) \\
\hline (1) Communication & 5.26 & 1.32 & 0.785 & 0.886 & & & & & & \\
\hline (2) Shared Values & 5.42 & 1.18 & 0.670 & $0.710^{* *}$ & 0.819 & & & & & \\
\hline (3) Perceived Benefits & 5.11 & 1.44 & 0.816 & $0.163 * *$ & $0.215^{* *}$ & 0.903 & & & & \\
\hline (4) Perceived Risk & 4.20 & 1.50 & 0.702 & 0.045 & $0.099 * *$ & $0.250 * *$ & 0.838 & & & \\
\hline (5) Trust & 4.61 & 1.44 & 0.718 & $0.424^{* *}$ & $0.411^{* *}$ & $0.097^{* *}$ & $0.326^{* *}$ & 0.847 & & \\
\hline (6) Commitment & 5.40 & 1.14 & 0.781 & $0.703 * *$ & $0.743 * *$ & $0.153 * *$ & 0.009 & $0.419^{* *}$ & 0.884 & \\
\hline (7) Investment intention & 5.42 & 1.09 & 0.731 & $0.700^{* *}$ & $0.729 * *$ & $0.190 * *$ & 0.068 & $0.425 * *$ & $0.814^{* *}$ & 0.855 \\
\hline
\end{tabular}

Notes: (1) ** indicates significance at the $1 \%$ level. (2) The value in Bold are the square root of AVE; Correlation coefficients between each latent variable from the 4th to the 10th column under each AVE. 


\subsection{Hypotheses Testing}

Taking SET and CVP as a theoretical base, we mainly tested Hypotheses 1-7, and discuss the findings based on the three mechanisms mentioned earlier. First, in order to enhance investor's trust, the roles of perceived risks, perceived benefits, communication, and shared values are discussed. Second, following Morgan and Hunt [28], the mediating role of trust on funding intention are examined. Finally, the direct impact of commitment on funding intention is also discussed.

Before testing the hypotheses, the identifiability of the SEM has been also examined, similarly to the CFA test mentioned above. The results show a high value of goodness-of-fit (NFI $=0.90, \mathrm{CFI}=0.92$, RMSEA $=0.076$ ). In addition, it is worth mentioning that the factor loading and measurement error for the control variables (i.e., reputation of the crowdfunding platform, the influence of the lead investor, and market prospects of the crowdfunding project) can be only set at 1 or 0 , as factor analysis mainly applied to continuous (i.e., randomized value) and polytomous (i.e., ordered value) variables, but not binary variables (i.e., binary value).

As can be seen in Figure 2, the coefficients of the reputation of the crowdfunding platform, the influence of the lead investor and the market prospects of the crowdfunding project were $\beta_{\text {PLATFORM }}$ $=0.180, \beta_{\text {LEADER }}=0.092$ and $\beta_{\text {MARKET }}=0.247$ respectively; all reached the level of significance. These findings indicate that a higher reputation of the crowdfunding platform, more influence of the lead investor, and more favorable marketing prospects of a crowdfunding project generated stronger investment intentions.

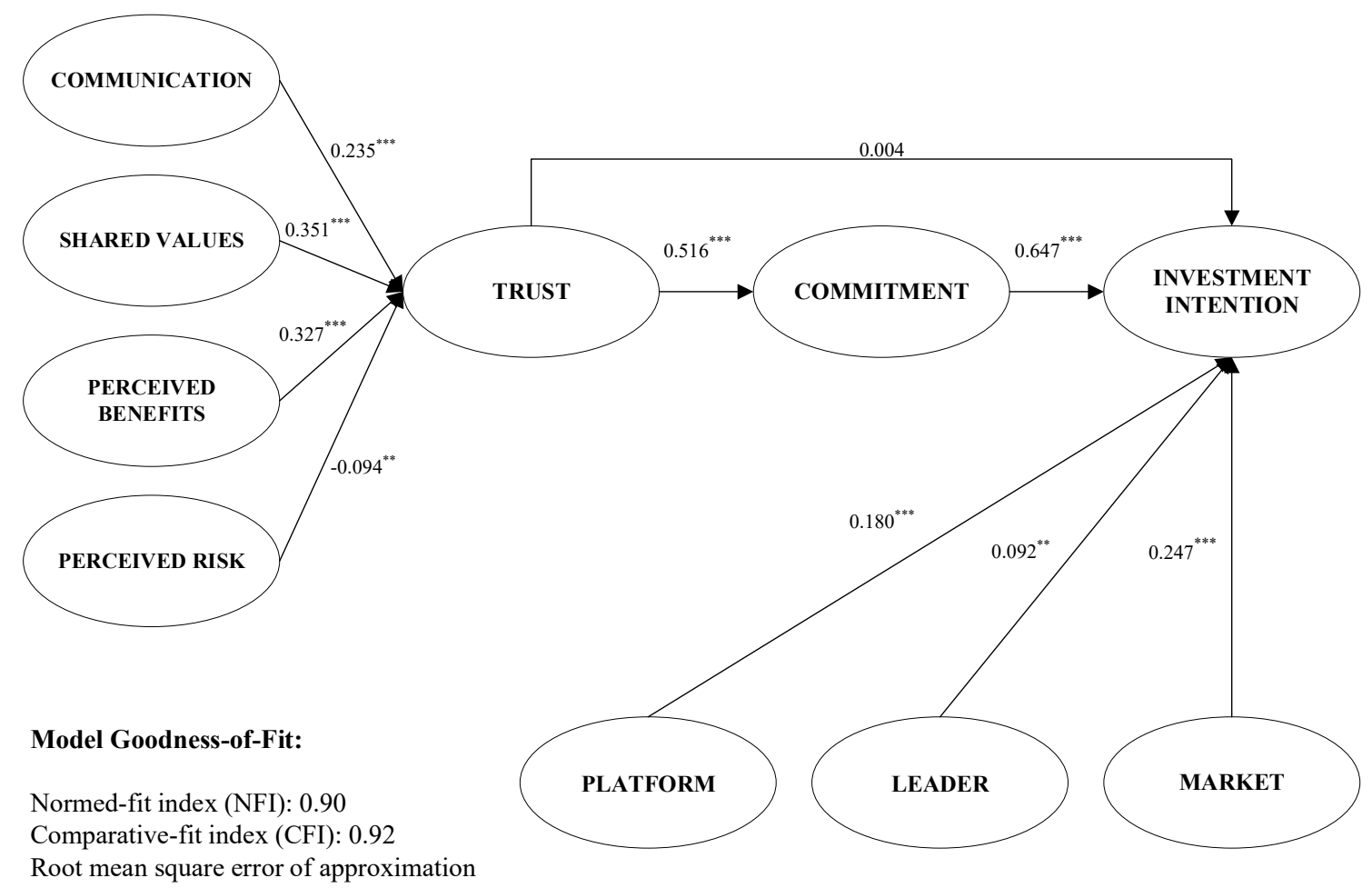

(RMSEA): 0.076

Figure 2. The estimation results of the model.

After controlling the effects of these three variables on crowdfunding investment intentions, a further SEM analysis was performed. The results show that communication had a significant positive effect on trust $\left(\beta_{\text {COMMUNICATION }}=0.235, p<0.001\right.$ ), indicating that more efficient communication between a crowdfunding fundraiser and investor generated stronger mutual trust, which supports Hypothesis 1 . The coefficient of perceived benefits on the level of trust was 0.327 , whereas that of perceived risks was -0.094 , both reached the level of significance. These findings are consistent with previous studies, that is, crowdfunding investors are more likely to trust a crowdfunding fundraiser if 
the project proposed shows great potential regarding various tangible and intangible benefits, including monetary profits or positive social effects in future. By contrast, investors were skeptical about a project proposed by a fundraiser with high perceived risks, as the uncertainty of decision-making and severity of the incorrect decision become greater; investors are more likely to exhibit negative reactions to trusting the fundraiser. Therefore, Hypotheses 3 and 4 were confirmed.

The coefficient of shared values was 0.351 , which also reached the level of significance, thus Hypothesis 2was accepted. Notably, the larger size of the coefficient indicates that values shared between investors and a fundraiser are likely to have a greater impact on forming trust, compared to perceived risks, perceived benefits, and communication. This finding implies that investors expect crowdfunding fundraisers to have commonly shared values with them. In many cases, 'creating shared values', such as managerial philosophy, universal value, lifestyle, problem-solving preferences, appears to be the most important predictor of investor's funding intention.

In addition to the findings regarding the first mechanism, this study also discusses the second influence mechanism (i.e., interactional effects between trust and commitment on funding intentions) The significantly positive direct effect of trust on a crowdfunding investor's commitment was supported (Hypothesis 5). This is consistent with many previous studies that claimed that trust strengthens funding intentions through fulfilling commitments $[62,63]$. Interestingly, we cannot find that the trust-level had a direct and significant effect on crowdfunding investment intentions ( $\beta_{\text {TRUST }}=0.004$, $p<0.889$ ), which rejects Hypothesis 6. Two possible reasons may explain this result. First, it may result from the heterogeneity among interviewees, such as preferences toward different products. Yin et al. [64] demonstrated that consumer trust for different brands of organic milk was different. In our case, interviewees may also develop the level of trust toward crowdfunding projects quite differently. As the focus of this study is to apply SET and CVP theories to the crowdfunding context but not to distinguish the differential effects of trust on crowdfunding intentions in response to various types of crowdfunding projects, different processes of trust formation may deviate the result from expectations. Second, the insignificant effect may result from the funding amount. Zhao et al. [3] found that if the funding amount is small relative to investors' income, investors are less likely to weigh the relationship between risk and funding intention. Similarly, the amount of funding in this study is also small relative to monthly income. According to the data, almost all of the interviewees had a monthly income above 5000 CNY (745.91 USD), whereas only $17.1 \%$ of interviewees invested more than 5000 $\mathrm{CNY}$ at one time. Therefore, investors do not really consider trusting crowdfunding fundraisers as a crucial factor that entices them to make the decision of investment.

Finally, regarding the last mechanism (the direct effect of commitment on funding intention), the coefficient of commitment on funding intention was 0.647 , with the level of significance. This suggests that when investors believe that fundraisers have the ability to take ownership and make and meet commitments, the funding intention of investors will be enhanced, thus Hypothesis 7 was confirmed.

Based on the above findings, the direct, indirect, and total effects of all variables on commitment and crowdfunding investment intentions are tabulated in Tables 3 and 4, respectively. On one hand, as Table 3 shows, trust has a weak intermediary effect and mediates the effects of communication, shared values, perceived benefits, and perceived risks on investors' commitment. On the other hand, as shown in Table 4, trust and commitment both have weak intermediary effects, and mediate the effects of communication and perceived benefits on crowdfunding investment intentions. However, trust and commitment both have strong intermediary effects, and completely mediate the effects of shared values and perceived risks on crowdfunding investment intentions. Furthermore, commitment is a strong intermediator, and completely mediates the effects of trust on crowdfunding investment intentions. 
Table 3. Direct, Indirect, and Total Effects (Standardized Absolute Value) of Latent Variables on Investors' Commitment.

\begin{tabular}{lccc}
\hline \multicolumn{1}{c}{ Variables } & Direct Effects & Indirect Effects & Total Effects \\
\hline (1) Communication & 0.077 & 0.007 & 0.084 \\
(2) Shared Value & 0.820 & 0.014 & 0.834 \\
(3) Perceived Benefits & -0.034 & -0.004 & -0.038 \\
(4) Perceived Risk & -0.083 & 0.014 & -0.069 \\
\hline
\end{tabular}

Table 4. Direct, Indirect, and Total Effects (Standardized Absolute Value) of Latent Variables on Investors' Investment intention.

\begin{tabular}{lccc}
\hline \multicolumn{1}{c}{ Variables } & Direct Effects & Indirect Effects & Total Effects \\
\hline (1) Communication & 0.088 & 0.035 & 0.123 \\
(2) Shared Values & 0.156 & 0.378 & 0.534 \\
(3) Perceived Benefits & 0.026 & -0.015 & 0.011 \\
(4) Perceived Risk & 0.018 & -0.040 & -0.022 \\
(5) Trust & -0.022 & 0.019 & -0.003 \\
\hline
\end{tabular}

\section{Conclusions}

Unlike previous studies, this study conceptualizes a theoretical framework that incorporates both social exchange (SET) and customer value perspective theories (CVP) for exploring the possible predictors of crowdfunding intentions in the context of mainland China. We assume three influence mechanisms that could enhance investor's crowdfunding intention: (1) through the latent impacts of communication, shared values, perceived risks, and perceived benefits on trust; (2) through the mediating effect of trust on commitment; and (3) through the direct effect of commitment on funding intention. We expect this study can provide conceptual guidance for policymakers in China for understanding the mechanism of crowdfunding participation, and the specific implementation paths for improving such a mechanism are also demonstrated.

The findings of the study indicate that communication, shared values, and perceived benefits have a positive association with investor's trust in fundraisers, which in turn have an influence on funding intention indirectly, while such an association for perceived risks is negative. Moreover, trust only exhibits an indirect and positive effect on funding intention through the process of commitment fulfillment. Its direct effect on funding intention is insignificant. In comparison, the positive effect of commitment on enhancing crowdfunding intention is significant. These findings are consistent with other studies on the specific effects of intangible factors, such as communication [65], shared values [66], or commitment [67]. However, the present study is one of few studies to interpret the structural and progressive relationships among these factors in a crowdfunding context.

\subsection{Theoretical Contribution}

This study mainly contributes to the literature in three ways. First, this study investigates crowdfunding investors' preferences and tendencies in the context of social commerce to facilitate crowdfunding. Specifically, both the CVP and SET, which have been widely studied, are adopted to investigate factors influencing crowdfunding investment intentions. Second, empirical research regarding the development of crowdfunding in China is insufficient. The findings of this paper, to a certain degree, identify several key determinants that impact crowdfunding intention in China. This will help deepen the innovation of the crowdfunding theory and gradually establish and improve the theoretical framework, adapting to China's realities. Third, trust does not have the expected direct positive effect on funding intention. This finding contributes to the literature by confirming that the presence of external factors, such as project features, can also lead to significant effects on outcome formation. 


\subsection{Managerial Contribution}

Based on the findings mentioned above, this study identifies the behavioral patterns of crowdfunding investors, whereby crowdfunding fundraisers can subjectively and objectively evaluate their projects to improve their crowdfunding outcomes. Three strategies for improving investor's crowdfunding participation are particularly proposed. First, expanding the function of crowdfunding platform to serve society and build the information resources in conformity with market economy, making sure the communication between fundraisers and investors is prompt, efficient, sufficient and reliable. Second, based on the accurate market positioning, fundraisers should exploit scientific methods to enhance perceived benefits of crowdfunding investors and to reduce their perceived risks, such as an accurate market positioning of the product. Crowdfunding platforms can facilitate this process using big data techniques to match certain needs among investors and fundraisers. Finally, investors' trust and commitment should be enhanced towards fundraisers. This further requires the development of a mature third-party guarantee mechanism that, under the premise of ensuring the safety of funds, controls the flow of funds if market risk is perceived as high.

Because of time, labor, and resource constraints, this study has the following limitations. First, although several data collection methods were utilized to verify the causal relationships between the independent and dependent variables, this study elected to perform a cross-sectional analysis. Thus, such relationships must be further verified with more rigorous evidence. Second, this study collected data from multiple sources; however, the data may suffer from common method bias. Third, although investment intentions do not necessarily equate to purchase behavior, this study did not explore the actual amounts of crowdfunding investment. Future studies can be conducted to fill this research gap. The limitations of this study indicate two viable research directions: (1) focus on representative crowdfunding platforms and use data collected through observations or from online platform operators to conduct a deeper analysis of crowdfunding investments; and (2) conduct a panel analysis to validate the SEM results and develop adaptive strategies for facilitating crowdfunding.

Author Contributions: X.Y. conceived and designed the experiments; X.T. performed the experiments and analyzed the data; X.Y., E.S., and K.Z. wrote the paper; K.Z. restructured, polished and revised the paper.

Acknowledgments: The authors gratefully acknowledge the financial aids from Natural Science Foundation of Beijing (Project No.9182003), Beijing Personal Project of Top Young Talents (Project No. 2016000026833ZS05), the research hatch fund of Guangzhou University (69-18ZX10191) and Chinese Postdoctoral Science Foundation (Project No. 2017M613092). All responsibility for the views expressed in the paper, however, should be attributed solely to the authors.

Conflicts of Interest: The authors declare no conflict of interest.

\section{References}

1. Pekmezovic, A.; Walker, G. The global significance of crowdfunding: Solving the SME funding problem and democratizing access to capital. Wm. Mary Bus. L. Rev. 2016, 7, 347.

2. Valanciene, L.; Jegeleviciute, S. Valuation of crowdfunding: Benefits and drawbacks. Econ. Manag. 2013, 18, 39-48. [CrossRef]

3. Zhao, Q.; Chen, C.D.; Wang, J.L.; Chen, P.C. Determinants of backers' funding intention in crowdfunding: Social exchange theory and regulatory focus. Telemat. Inf. 2017, 34, 370-384. [CrossRef]

4. Lehner, O.M. Crowdfunding social ventures: A model and research agenda. Ventur. Cap. 2013, 15, $289-311$. [CrossRef]

5. Meyskens, M.; Bird, L. Crowdfunding and value creation. Entrep. Res. J. 2015, 5, 155-166. [CrossRef]

6. World Bank. Crowdfunding's Potential for the Developing World; Info Dev; Finance and Private Sector Development Department: Washington, DC, USA, 2013.

7. Zhang, B.; Wardrop, R.; Rau, R.; Gray, M. Moving mainstream: Benchmarking the European alternative finance market. J. Financ. Perspect. 2015, 3, 60-76. 
8. Massolution. Global Crowdfunding Market to Reach \$34. 4B in 2015. Available online: http://www.crowdsourcing.org/editorial/global-crowdfunding-market-to-reach-344b-in-2015-predictsmassolutions-2015cf-industry-report/45376 (accessed on 22 June 2018).

9. Yuan, Y.; Chen, L. China Crowdfunding Industry Development Research; Shanghai Jiaotong University Press: Shanghai, China, 2018.

10. Xuefeng, L.; Zhao, W. Using crowdfunding in an innovative way: A case study from a Chinese crowdfunding platform. In Proceedings of the 2018 Portland International Conference on Management of Engineering and Technology (PICMET), Honolulu, HI, USA, 19-23 August 2018. [CrossRef]

11. Yue, C.; Zhang, W.; Yan, X. The life-cycle influence mechanism of the determinants of financing performance: An empirical study of a Chinese crowdfunding platform. Rev. Manag. Sci. 2018, 1-23. [CrossRef]

12. Zhao, Y. Regulation and supervision of internet finance and consumer protection in China. In Consumer Law and Socioeconomic Development; Springer: Cham, Switzerland, 2017.

13. Wei, S. Exploration on the crowdfunding mode of rural memory project. J. Landsc. Res. 2016, 8, 114-117.

14. Gerber, E.M.; Hui, J. Crowdfunding: Motivations and deterrents for participation. ACM Trans. Comput. Hum. Interact. 2016, 20, 34. [CrossRef]

15. Agrawal, A.; Catalini, C.; Goldfarb, A. The Geography of crowdfunding. SSRN Electron. J. 2011, 16820. Available online: https://www.nber.org/papers/w16820 (accessed on 21 February 2019). [CrossRef]

16. Hazen, T.L. Crowdfunding or fraudfunding? Social networks and the securities laws—Why the specially tailored exemption must be conditioned on meaningful disclosure. N. C. Law Rev. 2012, 90, 1735.

17. Ming, H.; Xi, L.; Shi, M. Product and pricing decisions in crowdfunding. Mark. Sci. 2015, 34, 331-345.

18. Belleflamme, P.; Lambert, T.; Schwienbacher, A. Crowdfunding: Tapping the right crowd. J. Bus. Ventur. 2014, 29, 585-609. [CrossRef]

19. Mollick, E. The dynamics of crowdfunding: An exploratory study. J. Business Venturing. 2014, $29,1-16$. [CrossRef]

20. Moss, T.W.; Neubaum, D.O.; Meyskens, M. The effect of virtuous and entrepreneurial orientations on microfinance lending and repayment: A signaling theory perspective. Entrep. Theory Pract. 2014, 39, $27-52$. [CrossRef]

21. Moon, Y.; Hwang, J. Crowdfunding as an alternative means for funding sustainable appropriate technology: Acceptance determinants of backers. Sustainability 2018, 10, 1456. [CrossRef]

22. Johnson, M.W.; Christensen, C.M.; Kagermann, H. Reinventing your business model. Harv. Bus. Rev. 2008, 86, 57-68. [CrossRef]

23. Chiu, C.-M.; Liang, T.-P.; Turban, E. Introduction to the special issue on crowdsourcing and social networks analysis. Decis. Support Syst. 2014, 65, 1-2. [CrossRef]

24. Colgren, D. The rise of crowdfunding: Social media, big data, cloud technologies. Strateg. Financ. 2014, 95, 56-57.

25. Yadav, M.S.; de Valck, K.; Hennig-Thurau, T.; Hoffman, D.L.; Spann, M. Social commerce: A contingency framework for assessing marketing potential. J. Interac. Mark. 2013, 27, 311-323. [CrossRef]

26. D'Rosario, M.; Busary, A.; Raval, K. The permissibility of crowd funding within South Asia: A comparative analysis of South Asian jurisdictions. In Financial Market Regulations and Legal Challenges in South Asia; IGI Global: Hershey, PA, USA, 2016; pp. 81-95.

27. Ferro, C.; Padin, C.; Svensson, G.; Payan, J. Trust and commitment as mediators between economic and non-economic satisfaction in manufacturer-supplier relationships. J. Bus. Ind. Mark. 2016, 31, 13-23. [CrossRef]

28. Morgan, R.M.; Hunt, S.D. The commitment-trust theory of relationship marketing. J. Mark. 1994, 58, $20-38$. [CrossRef]

29. Chang, H.H.; Tsai, Y.-C.; Chen, S.-H.; Huang, G.-H.; Tseng, Y.H. Building Long-term partnerships by certificate implementation: A social exchange theory perspective. J. Bus. Ind. Mark. 2015, 30, 867-879. [CrossRef]

30. Chou, S.-W.; Hsu, C.-S. Understanding online repurchase intention: Social exchange theory and shopping habit. Inf. Syst. E-Bus. Manag. 2016, 14, 19-45. [CrossRef]

31. Lioukas, C.S.; Reuer, J.J. Isolating Trust outcomes from exchange relationships: Social exchange and learning benefits of prior ties in alliances. Acad. Manag. J. 2015, 58, 1826-1847. [CrossRef]

32. Goodman, L.E.; Dion, P.A. The Determinants of commitment in the distributor-manufacturer relationship. Ind. Mark. Manag. 2001, 30, 287-300. [CrossRef] 
33. Gefen, D.; Karahanna, E.; Straub, D.W. Trust and tam in online shopping: An integrated model. MIS Q. 2003, 27, 51-90. [CrossRef]

34. Goldsby, M.G.; Kreiser, P.M.; Kuratko, D.F.; Bishop, J.W.; Hornsby, J.S. Social proactiveness and innovation: The impact of stakeholder salience on corporate entrepreneurship. J. Small Bus. Strateg. 2018, 28, 1-15.

35. MacMillan, K.; Money, K.; Money, A.; Downing, S. Relationship marketing in the not-for-profit sector: An extension and application of the commitment-trust theory. J. Bus. Res. 2005, 58, 806-818. [CrossRef]

36. Zehir, C.; Sahin, A.; Kitapçı, H.; Özşahin, M. The effects of brand communication and service quality in building brand loyalty through brand trust; the empirical research on global brands. Procedia Soc. Behav. Sci. 2011, 24, 1218-1231. [CrossRef]

37. Chao, C.-M.; Yu, C.-T.; Cheng, B.-W.; Chuang, P.-C. Trust and commitment in relationships among medical equipment suppliers: Transaction cost and social exchange theories. Soc. Behav. Personal. Int. J. 2013, 41, 1057-1069. [CrossRef]

38. Leonidou, L.C.; Samiee, S.; Aykol, B.; Talias, M.A. Antecedents and outcomes of exporter-importer relationship quality: Synthesis, meta-analysis, and directions for further research. J. Int. Mark. 2014, 22, 21-46. [CrossRef]

39. Chang, T.-S.; Hsiao, W.-H. Factors influencing intentions to use social recommender systems: A social exchange perspective. Cyberpsychol. Behav. Soc. Netw. 2013, 16, 357-363. [CrossRef]

40. Kuo, Y.F.; Feng, L.H. Relationships among community interaction characteristics, perceived benefits, community commitment, and oppositional brand loyalty in online brand communities. Int. J. Inf. Manag. 2013, 33, 948-962. [CrossRef]

41. Dhar, R.L. Service quality and the training of employees: The mediating role of organizational commitment. Tour. Manag. 2015, 46, 419-430. [CrossRef]

42. Angerer, M.; Niemand, T.; Kraus, S.; Thies, F. Risk-reducing options in crowdinvesting: An experimental study. J. Small Bus. Strateg. 2018, 28, 1-17.

43. Hong, I.B.; Cha, H.S. The mediating role of consumer trust in an online merchant in predicting purchase intention. Int. J. Inf. Manag. 2013, 33, 927-939. [CrossRef]

44. Cho, M.; Bonn, M.A.; Kang, S. Wine attributes, perceived risk and online wine repurchase intention: The cross-level interaction effects of website quality. Int. J. Hosp. Manag. 2014, 43, 108-120. [CrossRef]

45. Yu, M.C.; Mai, Q.; Tsai, S.B.; Dai, Y. An empirical study on the organizational trust, employee-organization relationship and innovative behavior from the integrated perspective of social exchange and organizational sustainability. Sustainability 2018, 10, 864. [CrossRef]

46. Cullen, B.; Johnson, L.; Sakano, T. Success through commitment and trust: The soft side of strategic alliance management. J. World Bus. 2000, 35, 223-240. [CrossRef]

47. See-To, E.W.K.; Ho, K.K.W. Value co-creation and purchase intention in social network sites: The role of electronic word-of-mouth and trust-A theoretical analysis. Comput. Hum. Behav. 2014, 31, 182-189. [CrossRef]

48. Ponte, E.; Carvajal-Trujillo, E.; Escobar-Rodríguez, T.; Bonsón Ponte, E.; Carvajal-Trujillo, E.; Escobar-Rodríguez, T.; Ponte, E.; Carvajal-Trujillo, E.; Escobar-Rodríguez, T. Influence of trust and perceived value on the intention to purchase travel online: Integrating the effects of assurance on trust antecedents. Tour. Manag. 2015, 47, 286-302. [CrossRef]

49. Moorman, C.; Deshpande, R.; Zaltman, G. Factors Affecting trust in market research relationships. J. Mark. 1993, 57, 81-101. [CrossRef]

50. Shin, J.I.; Chung, K.H.; Oh, J.S.; Lee, C.W. The effect of site quality on repurchase intention in internet shopping through mediating variables: The case of university students in South Korea. Int. J. Inf. Manag. 2013, 33, 453-463. [CrossRef]

51. Zopiatis, A.; Constanti, P.; Theocharous, A.L. Job involvement, commitment, satisfaction and turnover: Evidence from hotel employees in Cyprus. Tour. Manag. 2014, 41, 129-140. [CrossRef]

52. Featherman, M.S.; Pavlou, P.A. Predicting E-Services Adoption: A perceived risk facets perspective. Int. J. Hum. Comput. Stud. 2003, 59, 451-474. [CrossRef]

53. Mohr, J.J.; Spekman, R.E. Characteristics of partnership success: Partnership attributes, communication behavior, and conflict resolution techniques. Strateg. Manag. J. 1994, 15, 135-152. [CrossRef]

54. Cummings, T.G. Transorganizational development. Res. Organ. Behav. 1984, 6, 367-422.

55. Bauer, R.A. Consumer behavior as risk taking. In Risk Taking and Information Handling in Consumer Behavior; Cox, D.F., Ed.; Harvard University Press: Cambridge, MA, USA, 1960; pp. 389-398. 
56. Bhukya, R.; Singh, S. The effect of perceived risk dimensions on purchase intention. Am. J. Bus. 2015, 30, 218-230. [CrossRef]

57. Pavlou, A.P. Consumer acceptance of electronic commerce: Integrating trust and risk with the technology acceptance model. Int. J. Electron. Commer. 2003, 7, 69-103.

58. Jaros, S.; Jermier, J.; Koehler, J.; Sincich, T. Effects of Continuance, Affective, and Moral Commitment on the Withdrawal Process: An Evaluation of Eight Structural Equation Models. Acad. Manag. J. 1993, 36, 951-995. [CrossRef]

59. Kaiser, H.F. An index of factorial simplicity. Psychometrika 1974, 39, 31-36. [CrossRef]

60. Tobias, S.; Carlson, J.E. Bartlett's Test of sphericity and chance findings in factor analysis. Multivar. Behav. Res. 1969, 4, 375-377. [CrossRef] [PubMed]

61. Wood, J.M.; Tataryn, D.J.; Gorsuch, R.L. Effects of under- and over- extraction on principal axis factor analysis with varimax rotation. Psychol. Methods 1996, 1, 354-365. [CrossRef]

62. Lambert, T.; Schwienbacher, A. An empirical analysis of crowdfunding. Soc. Sci. Res. Netw. 2010, 1578175, $1-23$.

63. Ordanini, A.; Miceli, L.; Pizzetti, M. Crowdfunding: Transforming Customers into investors through innovative service platforms. J. Serv. Manag. 2010, 22, 443-470. [CrossRef]

64. Yin, S.; Chen, M.; Chen, Y.; Xu, Y.; Wang, Y. Consumer trust in organic milk of different brands: The role of Chinese organic label. Br. Food J. 2016, 118, 1769-1782. [CrossRef]

65. Solomonson, W.L. Trust and the client-consultant relationship. Perform. Improv. Q. 2012, 25, 53-80. [CrossRef]

66. Valančienè, L.; Jegelevičiūtè, S. Crowdfunding for creating value: Stakeholder approach. Procedia Soc. Behav. Sci. 2014, 156, 599-604. [CrossRef]

67. Sargeant, A.; Ford, J.B.; West, D.C. Perceptual determinants of non-profit giving behavior. J. Bus. Res. 2006, 59, 155-165. [CrossRef]

(C) 2019 by the authors. Licensee MDPI, Basel, Switzerland. This article is an open access article distributed under the terms and conditions of the Creative Commons Attribution (CC BY) license (http://creativecommons.org/licenses/by/4.0/). 